\title{
EDUKASI COVID-19 BAGI WARGA LANSIA DI RW 05 KELURAHAN JATICEMPAKA PONDOKGEDE
}

\author{
Mega Elvianasti1), Liszulfah Roza ${ }^{2)}$, Maesaroh $^{1)}$, Husnin Nahry Yarza') \\ 1)Pendidikan Biologi, FKIP, Universitas Muhammadiyah Prof. Dr. Hamka, Jakarta, Indonesia \\ 2) Pendidikan Fisika, FKIP, Universitas Muhammadiyah Prof. Dr. Hamka, Jakarta, Indonesia \\ Corresponding author : Mega Elvianasti \\ E-mail : megaelvianasti@uhamka.ac.id
}

Diterima 20 Maret 2021, Direvisi 03 April 2021, Disetujui 03 April 2021

\begin{abstract}
ABSTRAK
Virus Corona atau Severe Acute Respiratory Syndrome Coronavirus 2 (SARS-CoV-2) adalah jenis virus yang menyerang sistem pernapasan dan kekebalan tubuh manusia. Di Indonesia sendiri jumlah orang yang terinfeksi terus meningkat karena masih kurangnya kesadaran masyarakat untuk menerapkan protokol kesehatan. Orang yang terinfeksi Covid-19 memiliki gejala yang berbeda satu sama lain. Ada yang menyebabkan gangguan ringan pada sistem pernapasan, infeksi paru-paru yang berat, hingga kematian. Virus Corona ini adalah jenis baru dari Coronavirus yang menular ke manusia. Virus ini bisa menyerang siapa saja, mulai dari bayi, anak-anak, orang dewasa, ibu hamil dan ibu menyusui serta lansia. Bahkan lansia menjadi kelompok orang yang paling beresiko tertular. Berdasarkan wawancara dengan beberapa lansia, mereka mereka belum memiliki pemahaman dan pengetahuan yang benar mengenai Covid-19, selain itu dalam penyampaian informasi kepada lansia tidak memungkinkan untuk dilakukan secara online. Tujuan dari kegiatan ini adalah untuk memberikan edukasi tentang COVID-19 kepada masyarakat khususnya kepada lansia yang berada di RW 05 Kelurahan Jaticempaka Pondokgede Bekasi. Langkah-langkah yang dilakukan dalam kegiatan pengabdian ini, yaitu 1) Sosialisasi kepada mitra 2) mendata jumlah lansia yang ada di Kelurahan Jaticempaka RW 05, 3) Menyiapkan media edukasi dengan menggunakan x banner, 4) Memberikan edukasi covid-19 dengan cara door to door untuk menghindari kerumunan ,5) Memberikan bantuan pangan kepada warga lansia dan warga yang terdampak covid-19. Hasil dari kegiatan para lansia dapat memahami apa itu virus Covid-19, bagaimana penyebarannya, dan bagaimana menerapkan protokol kesehatan sehingga terhindar dari infeksi virus Covid-19.
\end{abstract}

Kata Kunci: edukasi; lansia; covid-19.

\begin{abstract}
Coronavirus or Severe Acute Respiratory Syndrome Coronavirus 2 (SARS-CoV-2) is a type of virus that attacks the human respiratory and immune systems. In Indonesia, the number of infected people continues to increase due to the lack of public awareness to apply health protocols. People infected with Covid-19 have different symptoms from one another. Some cause minor problems in the respiratory system, severe lung infections, and death. This Corona virus is a new type of Coronavirus that is transmitted to humans. This virus can attack anyone, from infants, children, adults, pregnant and nursing mothers and the elderly. Even the elderly are the group of people most at risk of contracting it. Based on interviews with several elderly people, they do not have the correct understanding and knowledge about Covid-19, besides that it is not possible to convey information to the elderly people online. The purpose of this activity is to provide education about COVID-19 to the community, especially to the elderly who are in RW 05 Jaticempaka Pondokgede Bekasi Village. The steps taken in this service activity are 1) Outreach to partners 2) recording the number of elderly people in Jaticempaka Village RW 05, 3) Preparing educational media using $x$ banners, 4) Providing covid-19 education by means of door to door to avoid crowds, 5) Providing food assistance to elderly residents and residents affected by Covid-19. The results of the activities of the elderly can understand what the Covid-19 virus is, how it spreads, and how to implement health protocols to avoid Covid-19 virus infection.
\end{abstract}

Keywords: education; elderly people; covid-19

\section{PENDAHULUAN}

Penduduk dunia masih dihadapkan pada wabah pandemi yang diakibatkan oleh virus yang baru ditemukan. Virus ini pertama kali muncul di daratan China tepatnya di Wuhan lbu kota provinsi Hueibei. Virus Corona atau 
Severe Acute Respiratory Syndrome Coronavirus 2 (SARS-CoV-2) adalah virus yang menyerang sistem pernapasan. Penyakit karena virus ini disebut Covid-19. Virus ini menyebabkan gangguan ringan pada sistem pernapasan, infeksi paru-paru yang berat, hingga kematian. Virus Corona ini adalah jenis baru dari Coronavirus yang menular ke manusia. Menurut data WHO tanggal 19 Maret 2021 di seluruh dunia telah terkonfirmasi sebanyak 122 juta orang terinfeksi virus ini dan terkonfirmasi sebanyak 2,69 juta orang meninggal dunia. Sedangkan di Indonesia, update data orang yang terinfeksi virus ini sebanyak 1,45 juta dan yang meninggal dunia sebanyak 39.339 orang (Gugus Tugas Percepatan Penanganan Covid-19). Kematian paling banyak terjadi pada kelompok lansia. Virus ini bisa menyerang siapa saja, mulai dari bayi, anak-anak, orang dewasa, ibu hamil dan ibu menyusui serta lansia. Bahkan lansia menjadi kelompok orang yang paling beresiko tertular. Jumlah dan proporsi penduduk berusia 60 tahun ke atas semakin meningkat. Pada 2019, jumlah penduduk usia 60 tahun ke atas adalah 1 miliar. Jumlah ini akan meningkat menjadi 1,4 miliar pada tahun 2030 dan 2,1 miliar pada tahun 2050. Menurut kajian (Vahia et al, 2020) data dari berbagai penelitian membandingkan bahwa betapa sulitnya pandemik Covid-19 bagi kelompok lansia. Banyak para lansia tidak memiliki sumber daya yang diperlukan untuk mengatasi stres menghadapi Covid-19. Misalnya : kurangnya akses teknologi pintar, sosial, kognitif atau biologis (misalnya ketidakmampuan untuk terlibat dalam latihan fisik atau berpartisipasi dalam kegiatan rutinitas.

Orang lanjut usia merupakan kelompok yang paling rentan, namun masih sangat sedikit sikap dan kepatuhan orang lanjut usia untuk mematuhi tindakan pencegahan Covid-19 (Daoust, 2020).

Hal ini yang melatarbelakangi relawan Universitas Muhammadiyah Prof.DR.Hamka (UHAMKA) untuk melakukan kegiatan sosial berupa edukasi tentang Covid-19 kepada masyarakat khususnya kepada lansia yang berada di RW 05 Kelurahan Jaticempaka Pondokgede Bekasi. Kegiatan ini berupa edukasi kepada lansia berupa pemahaman tentang Covid-19 dan bagaimana menyikapinya serta penerapan pola hidup sehat agar terhindar dari penyebaran virus ini, seperti : cara mencuci tangan yang benar, dan memakai masker yang benar. Ada 7 kegiatan yang direkomendasikan WHO untuk mencegah penularan virus corona, yaitu :
1. Selalu mencuci tangan dengan sabun dan air bersih atau menggunakan cairan mengandung alkohol.

2. Melakukan jarak minimal 1 meter dengan orang yang batuk dan bersin.

3. Hindari menyentuh wajah.

4. Tutup mulut dan hidung saat batuk dan bersin.

5. Tetap di rumah jika merasa kurang sehat.

6. Jangan merokok dan melakukan aktivitas yang dapat melemahkan kinerja paru-paru.

7. Tetap jaga jarak, hindari perjalanan yang tidak perlu dan menjauh dari keramaian.

(Armitage \& Nellums, 2020) berpendapat agar para lansia tidak tertular Covid-19 adalah menginstruksikan mereka untuk tetap di rumah, memiliki persediaan bahan makanan dan obat-obatan, dan menghindari kontak sosial dengan keluarga atau teman-teman. Selain itu, teknologi online dapat dimanfaatkan untuk memberikan dukungan sosial. Terapi perilaku kognitif dapat dilakukan secara online untuk mengurangi kesepian dan meningkatkan kesejahteraan mental lansia. Tindakan isolasi para lansia ini dapat mengurangi transmisi dan meminimalkan penyebaran Covid-19 terhadap kelompok ini.

$$
\text { Kegiatan ini bertujuan untuk }
$$

memberikan pemahaman kepada lansia mengenai Covid-19, karena kurangnya informasi yang diberikan kepada lansia dan cara penyampaian informasi yang sulit dipahami oleh lansia. Teknis kegiatan ini dilakukan secara door to door untuk menghindari kerumunan dan tetap jaga jarak serta memperhatikan protokol kesehatan.

\section{METODE}

Kelurahan Jaticempaka berada di kecamatan pondokgede, kota bekasi. Wilayahnya berbatasan langsung dengan wilayah pangkalan jati, DKI Jakarta. Kegiatan pengabdian ini dilakukan di RW 05 Jaticempaka. Edukasi ini dikhususkan untuk warga lansia, karena jumlah lansia yang lebih dari 10 orang sehingga edukasi ini perlu dilakukan karena minimnya informasi yang diterima warga lansia. Permasalahan mitra dapat dirumuskan dalam dua aspek, yaitu :

1. Kurangnya pemahaman lansia mengenai Covid-19.

2. Lansia adalah salahsatu kelompok yang terdampak Covid-19 secara ekonomi

Target yang ingin dicapai dengan adanya kegiatan ini adalah kelompok lansia mendapatkan bantuan secara sosial dan ekonomi. Secara sosial kelompok lansia mendapatkan pemahaman yang baik tentang virus Covid-19, bagaimana penyebarannya, bagaimana pencegahan Covid-19 dan apa saja 
yang harus dilakukan oleh kelompok lansia agar terhindar dari infeksi virus tersebut karena kelompok lansia adalah yang paling rentan terinfeksi. Menurut pusat pengendalian dan pencegahan penyakit di China, angka kematian pada kelompok usia 60 hingga 69 tahun adalah $3,6 \%$ dan dapat mencapai hingga $18 \%$ pada usia 80 tahun ke atas. Dengan meningkatnya kerentanan, ada juga peningkatan ketakutan, kepanikan. Kesehatan mental merupakan landasan kesehatan masyarakat, terlebih pada lansia karena kepanikan hanya membantu meningkatkan penyebarannya (Banerjee, 2020)

Selain bantuan sosial diberikan bantuan secara ekonomi berupa pemberian paket sembako, hal ini bertujuan agar kelompok lansia dapat menunjang kebutuhan sehari-hari di masa pandemik Covid-19.

Adapun kegiatan yang telah dilakukan terkait dengan pelatihan ini adalah:

1. Tahap persiapan, meliputi:

a) Melakukan rapat koordinasi dengan mitra.

b) Melakukan pendataan jumlah warga lansia yang ada di RW 05 kelurahan jaticempaka.

2. Tahap pelaksanaan, meliputi:

a) Persiapan media edukasi yaitu $x$ banner dan paket sembako

b) Mengunjungi kelompok lansia secara door to door untuk menghindari keramaian dan mengikuti protokol kesehatan.

c) Memberikan edukasi dan paket sembako kepada kelompok lansia.

3. Tahap evaluasi dan monitoring dengan melakukan wawancara langsung mengenai pemahaman lansia tentang Covid-19 setelah diberikan edukasi.

\section{HASIL DAN PEMBAHASAN}

Kegiatan pengabdian yang dilakukan dalam bentuk bantuan secara social berupa edukasi dan ekonomi berupa bantuan pangan, kegiatan ini dilaksanakan dalam dua hari dengan rincian kegiatan sebagai berikut :

1. Persiapan bantuan pangan yang akan dibagikan kepada warga lansia

Bantuan ekonomi berupa sembako diberikan untuk menunjang kehidupan sehari-hari para lansia karena dikhawatirkan anggota keluarga juga mengalami kesulitan ekonomi akibat wabah Covid-19. Yayasan Nurul Hidayah selaku mitra dalam pengabdian ini membantu dalam pembelian, pengepakan dan pembagian sembako pada lansia.

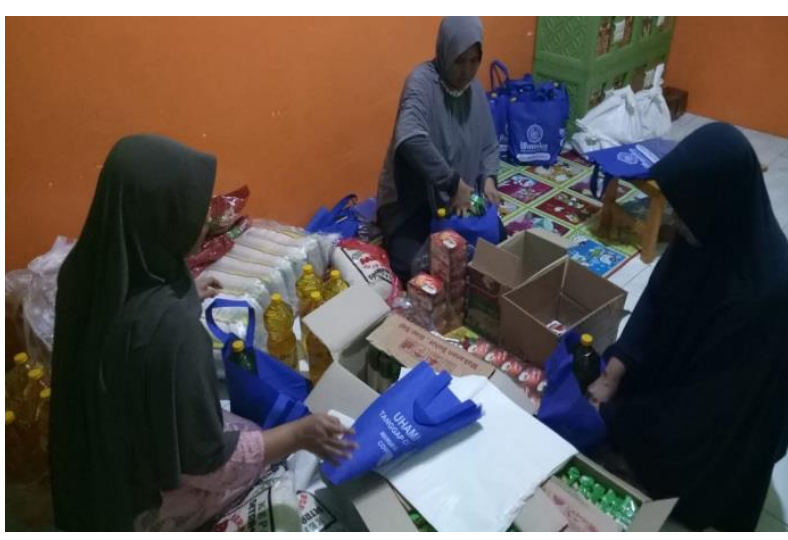

Gambar 1. Persiapan pembagian sembako

Sembako yang telah diberikan berupa beras 5 $\mathrm{kg}$, minyak goreng 2 liter, teh, gula $1 \mathrm{~kg}$, dan mie instan sebanyak 5 bungkus.

2. Menyiapkan media edukasi yaitu $x$ banner agar mudah untuk dilihat dan dipahami oleh lansia

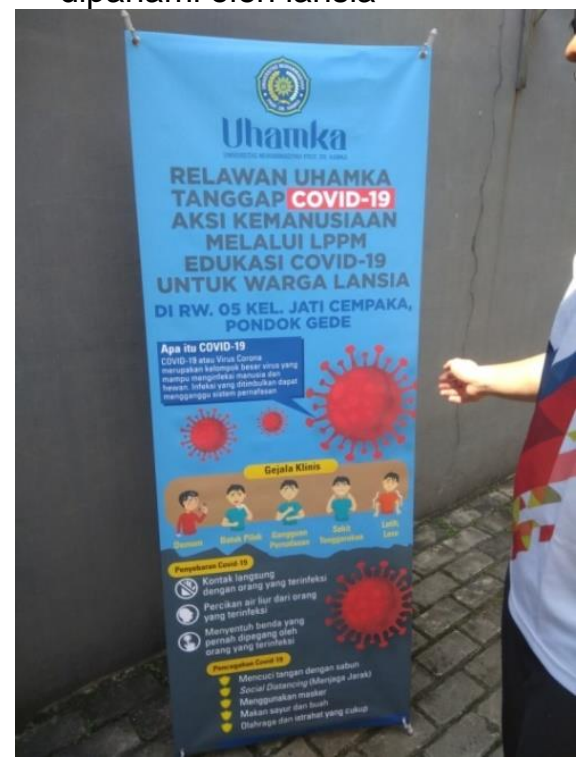

Gambar 2. x banner media edukasi

Salah satu pertimbangan penggunaan $\mathrm{x}$ banner sebagai media edukasi adalah karena mudah dilihat dengan tulisan yang besar sehingga memudahkan kelompok lansia untuk membaca dan memahami. X banner ini juga ditambahkan gambar-gambar sebagai ilustrasi untuk memudahkan kelompok lansia dalam memahami tentang virus Covid-19. 
3. Proses edukasi dan pembagian bantuan berupa sembako

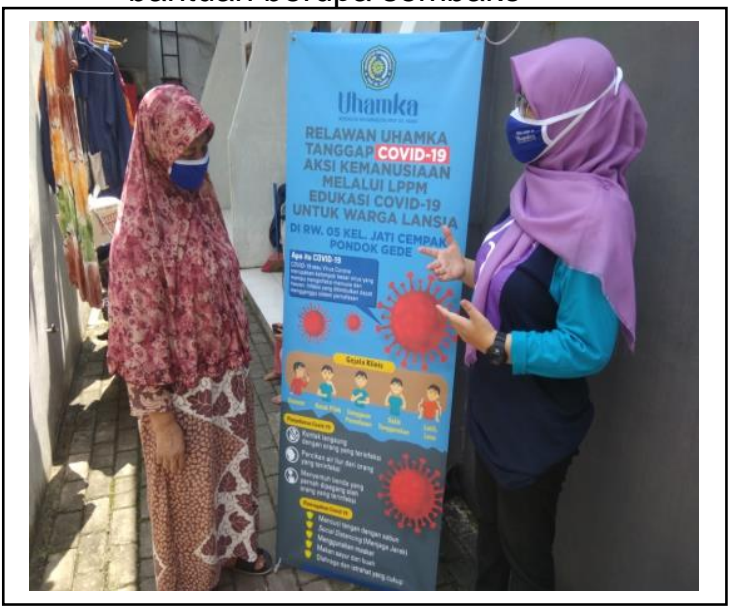

Gambar 3. Edukasi covid-19

Dengan memperhatikan protokol kesehatan, pada sesi edukasi ini dilakukan sosial distancing, pemberian masker dan hand sanitizer serta mengindari kerumunan.

Beberapa hal yang dijelaskan kepada kelompok lansia, yaitu :

1. Apa itu virus Covid-19?

2. Bagaimana penyebaran virus Covid-19?

3. Bagaimana mencegah virus Covid-19?

4. Hal apa saja yang bisa dilakukan oleh kelompok lansia agar terhindar dari virus Covid-19?

Setelah disampaikan hal-hal yang mendasar mengenai virus Covid-19, kelompok lansia diberikan beberapa pertanyaan, seperti :

1. Apakah sudah paham tentang virus Covid19 ?

2. Kegiatan yang sering dilakukan lansia sehingga berpotensi terjadi penularan? Hampir semua lansia menjawab bahwa tidak memakai masker ketika belanja ke tukang sayur.

3. Dari mana lansia memeroleh informasi mengenai virus Covid-19? Keseluruhan lansia menjawab dari televisi dan belum ada orang yang menjelaskan informasi mengenai Covid-19 kepada mereka.

Berikut rekomendasi untuk orang lanjut usia: (1) Perhatian perlu diberikan kepada kelompok rentan, terutama penduduk lanjut usia; (2) aksesibilitas sumber daya medis dan sistem pelayanan kesehatan masyarakat harus lebih diperkuat dan ditingkatkan, khususnya setelah meninjau penanganan awal dan pengelolaan Epidemi Covid-19; (3) perencanaan strategis nasional dan koordinasi untuk pertolongan pertama psikologis selama bencana besar, yang berpotensi dikirimkan melalui pengobatan jarak jauh, harus dilakukan
Secara matang; dan (4) pencegahan krisis yang komprehensif dan sistem intervensi, termasuk pemantauan epidemiologi, skrining, rujukan dan intervensi yang ditargetkan, harus dibangun untuk mengurangi tekanan psikologis dan mencegah mental lebih lanjut masalah kesehatan di antara populasi ini (Javadi \& Nateghi, 2020)

\section{SIMPULAN DAN SARAN}

Berdasarkan kegiatan pengabdian masyarakat yang telah dilakukan dapat diambil kesimpulan bahwa kelompok lansia yang berada di kelurahan jaticempaka mendapatkan informasi yang memadai mengenai virus Covid19 dan secara ekonomi, kelompok lansia juga mendapatkan bantuan pangan berupa sembako.

Evaluasi kegiatan pengabdian masyarakat didapat beberapa saran dan rekomendasi sebagai yaitu diperlukan media lain selain $x$ banner untuk menyampaikan materi mengenai Covid-19 dan wilayah sasaran edukasi Covid19 untuk kelompok lansia dapat diperluas atau ditambah.

\section{DAFTAR RUJUKAN}

Armitage, R., \& Nellums, L. B. (2020). COVID19 and the. The Lancet Public Health, $5(5)$, e256. https://doi.org/10.1016/S24682667(20)30061-X

Banerjee, D. (2020). The impact of Covid-19 pandemic on elderly mental health. International Journal of Geriatric Psychiatry, 35(12), 1466-1467. https://doi.org/10.1002/gps.5320

Daoust, J. F. (2020). Elderly people and responses to COVID-19 in 27 Countries. PLOS ONE, 15(7), 1-13. https://doi.org/10.1371/journal.pone.02 35590

Javadi, S. M. H., \& Nateghi, N. (2020). COVID19 and Its Psychological Effects on the Elderly Population. Disaster Medicine and Public Health Preparedness, 14(3), e40-e41.

https://doi.org/10.1017/dmp.2020.245

Gugus Tugas Percepatan Penanganan Covid 19. Diakses tanggal 1 Juni 2020.

World Health Organization. (2020). Coronavirus disease 2019 ( COVID-19) situation : report, 51

Viewpoint, T., \& Con-, D. (2020). Older Adults and the Mental Health Effects of COVID-19. 2019, 2020-2021. https://doi.org/10.1093/geronb/gbaa12 0 